\title{
ANALISIS VIDEO LIKES TO SUBSCRIBER RATIO YOUTUBE PADA 5 YOUTUBER TERKAYA DI INDONESIA
}

\author{
I Putu Eka Pratama Juniartana \\ STIMIK STIKOM Indonesia \\ senseimxn@gmail.com
}

\begin{abstract}
ABSTRAK
Teknologi informasi dan komunikasi saat ini telah berkembang dengan pesat, hal ini membuat semakin banyak jenis aplikasi sosial media yang muncul dengan fitur dan fungsi yang berbeda-beda. Salah satu aplikasi sosial media yang sering digunakan dan memiliki pengaruh besar adalah YouTube. Penelitian ini dilakukan dengan tujuan untuk menemukan rasio-rasio yang terdapat pada akun YouTube. Rasio-rasio ini yang nantinya akan digunakan untuk mengukur performa sebuah akun secara matematis. Penelitian ini dilakukan dengan menggunakan metode ekploratif untuk menemukan variabel-variabel yang terdapat pada akun YouTube. Variabel tersebut yang nantinya akan dibandingkan dan disandingkan untuk diuji relevansinya sehingga menjadi rasio yang relevan. Rasio yang relevan akan digunakan untuk menilai performa setiap akun yang ada pada sosial media YouTube.

Hasil dari penelitian sosial media youtube ini menunjukan bahwa terdapat 6 variabel, variabel tersebut diantaranya yaitu post, subscriber, likes, dislikes, viewers, comments. Keenam variabel tersebut yang nantinya akan dibandingkan dan disandingkan sehingga menemukan 10 rasio yang relevan. Manfaat yang dapat diambil dari penelitian ini yaitu kedepannya dapat menilai, mengukur serta membandingkan kredebilitas dari setiap akun youtube dengan mudah menggunakan 10 rasio yang telah ditemukan.
\end{abstract}

\section{PENDAHULUAN}

YouTube adalah sebuah situs web video sharing (berbagi video) yang populer dimana para pengguna dapat memuat, menonton, dan berbagi klip video secara gratis. Didirikan pada bulan februari 2005 oleh 3 orang mantan karyawan PayPal, yaitu Chad Hurley, Steve Chen dan Jawed Karim. Umumnya video-video di YouTube adalah video klip film, TV, serta video buatan para penggunanya sendiri. (Tjanatjantia. Widika, 2013) Dilansir dari statistik dalam 
situsnya sendiri, Youtube memiliki lebih dari satu milyar pengguna yang merupakan hampir sepertiga semua pengguna internet. Hingga Maret 2015, pembuat konten di Youtube sudah mengunggah 10.000 video, karena membuat akun atau channel di Youtube dan meraih pelanggan atau penayangan bisa menghasilkan uang.

Saat ini Youtube menjadi situs online Video provider paling dominan di Amerika serikat, bahkan dunia, dengan menguasai 43\% pasar. Diperkirakan 20 Jam durasi video di upload ke Youtube setiap menitnya dengan 6 miliar views per hari. Youtube kini telah menjadi berbagai macam kebutuhan dari penggunanya, fiturfitur yang ditawarkan dengan kemajuan teknologi Youtube saat ini sangat membantu dari berbagai aspek kebutuhan yang dibutuhkan sang pengguna. Jumlah jam yang diluangkan orang-orang untuk menonton video (alias waktu tonton) di YouTube naik 60\% per tahunnya, dan merupakan pertumbuhan terpesat yang pernah dilihat dalam kurun waktu 2 tahun terakhir. Jumlah orang yang menonton YouTube per hari naik sebesar $40 \%$ per tahun sejak Maret 2014.Jumlah pengguna yang mengunjungi YouTube dan memulainya dari beranda YouTube, naik lebih dari 3 kali lipat per tahun. (youtube, 2016)

Sejauh ini para peneliti sudah ada yang melakukan penelitian pada aplikasi YouTube contohnya seperti penelitian pemanfaatan YouTube sebagai media ajar, pengembangan video blog pada YouTube, pengaruh Vlogger terhadap suatu produk yang dipromosikan dan lain sebagainya. Dari beberapa penelitian yang telah dilakukan belum ada peneliti yang melakukan penelitian untuk mencari rasio-rasio yang terdapat pada akun YouTube. Tujuan penelitian ini ialah untuk menemukan rasio-rasio yang terdapat pada YouTube yang kemudian setiap variabel dilakukan perbandingan sehingga menjadi rasio yang relevan. Rasio-rasio ini nantinya akan digunakan untuk menilai performa dan kredibilitas yang ada pada sebuah akun YouTube. Penelitian ini menggunakan metode penelitian eksploratif, karena pada dasarnya penelitian eksploratif digunakan untuk merumuskan masalah secara lebih terperinci atau menggambarkan hipotesis bukan menguji hipotesis.

Kredibilitas sebuah akun dapat diukur dari performa akun yang harus diukur secara sistematis. Dalam mengukur performa dari sebuah akun diperlukan skala pengukuran yang akan tertuang kedalam rasio-rasio. Ada berbagai macam skala pengukuran, diantaranya yaitu : skala nominal, skala ordinal, skala interval, dan skala rasio. Skala pengukuran tersebut yang akan menimbulkan data berupa rasio. Akun YouTube yang dapat dianalisis untuk menentukan kredibilitas, harus memenuhi syarat pada pengaturan akun pada YouTube. Persyaratan tersebut 
diantaranya yaitu, akun YouTube merupakan akun yang bersifat publik, video yang diposting tidak dikunci (privacy) dan kolom komentar tidak di non-aktifkan (disable).

\section{TINJAUAN PUSTAKA}

Youtube merupaka sebuah platform media sosial yang menyimpan dan menyiarkan postingan berupa video yang dapat diakses dimanapun pada jaringan internet. Seluruh orang dapat menggunggah video kedalam platform Youtube dengan syarat memiliki akun google dan digunakan sebagai akun Youtube, Youtube saat ini merupakan Aplikasi dibawah layanan Google. Youtube memberikan kebebasan durasi dalam pengunggahan video pada platformnya, dan video yang telah diunggah bersifat gratis, dan juga memungkinkan mendapatkan bayaran (monetize) dari layanan Google Adsense dengan mengizinkan iklan untuk diputar pada video yang diunggah, namun pada 2019, seluruh video yang diputar pada media Youtube sudah otomatis menampilkan iklan, untuk menonton video tanpa iklan di Youtube, para penonton harus berlangganan layanan bebas iklan pada Platform ini.

YouTube sebagai salah satu media yang sangat digemari oleh anak muda saat ini. Popularitas YouTube salah satunya adalah terkait dengan fakta bahwa konten di media digital dalam bentuk video sedang menjamur (Nielsen, 2016; Vollmer, 2017; We Are Social, 2017). Seiring dengan meningkatnya penetrasi internet, terus dibangunnya infrastruktur teknologi komunikas i, ser ta menjamurnya smartphone, kini semakin banyak masyarakat Indonesia, terutama di kota- kota besar, yang memiliki kebiasaan untuk mengkonsumsi konten berbentuk audio visual lewat beragam gawai yang ada. Kebanyakan kreator konten masih membua t kon $\mathrm{t}$ en yang be $\mathrm{r} \mathrm{s}$ i fa $\mathrm{t}$ mainstream. Oleh karena itu di masa mendatang pihak YouTube ingin semakin memperbanyak kreator konten dan komunitas YouTuber yang berfokus pada konten yang bersifat edukatif (ibid). Dengan beragam basis argumen yang dikemukakan di atas, artikel ini berfokus pada Pemetaan Konten Pendidikan Berbasis Audio-Visual di Media Sosial YouTube

\section{METODE PENELITIAN}

Penelitian ini menggunakan metode eksploratif kuantitatif untuk mengetahui kredibilitas dari performa akun Youtube 5 Youtuber Terkaya Di Indonesia. Metode eksploratif merupakan penelitian yang memiliki tujuan untuk melakukan eksplorasi atau memperdalam 
pengetahuan ataupun ide-ide baru mengenai suatu hal yang baru, guna merumuskan permasalahan secara terperinci (Maryam, Isrok'atun, and Aeni 2016) .

Tujuan dari penelitian ini yaitu mengetahui nilai kredibillitas dari performa akun Youtube 5 Youtuber Terkaya Di Indonesia. Ada beberapa langkah yang harus dilakukan dalam penelitian ini, sehingga mampu menemukan peringkat pertama akun Youtube 5 Youtuber Terkaya Di Indonesia yang memiliki performa terbaik. Langkah-langkah yang dilakukan pada penelitian ini, diantaranya yaitu :

\section{Melakukan Eksplorasi Pada Website Untuk Menentukan Objek yang Akan}

\section{Dianalisa.}

Eksplorasi ini dilakukan pada beberapa halaman website yang menyediakan informasi mengenai objek yang akan di teliti. Setelah ekslorasi selesai dilakukan, sehingga ditemukan nama-nama vendor smartphone di Indonesia yang akan dijadikan objek analisa. Setelah melakukan eksplorasi pada halaman website, maka langkah selanjutnya yaitu mencari nama akun Youtube dari masing-masing youtuber. Pastikan semua youtuber memiliki akun pada aplikasi youtube.

\section{Menghitung Nilai Rata-Rata Variable Dari Top 5 Vendor Smartphone di} Indonesia.

Pada langkah ini, peneliti menghitung nilai variable Likes dan Subscriber Variabel merupakan sesuatu yang memiliki nilai bervariasi dimana nilai tersebut dapat dijadikan sebagai dasar untuk empat data yang berbeda seperti rasio, skala, ordinal, nominal dan internal (Rankuti 2015) . Untuk menghitung nilai rata-rata dari variabel Likes dan Subscriber yaitu dengan cara mengambil minimal 10 postingan kemudian di hitung sehingga menemukan nilai rata-rata dari masing-masing variabel. 


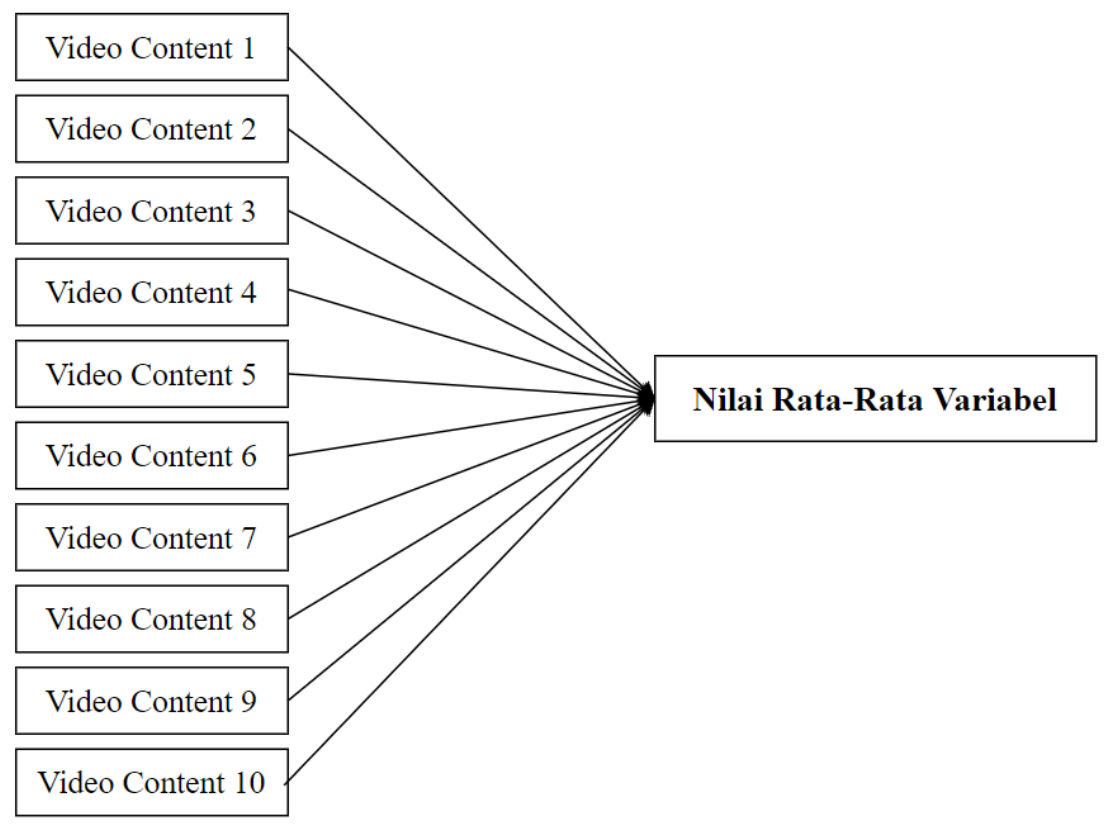

\section{Menghitung Nilai Kredibilitas Rasio}

Untuk menghitung nilai kredibilitas dari video comments to video views ratio, peneliti menggunakan cara membagi nilai variabel pertama dengan nilai variabel kedua. Jika Likes memiliki nilai 100 dan Subscriber memiliki nilai 300, maka cara menghitungnya yaitu $100: 300=0,3$. Dengan begitu nilai dari video comments to video views ratio adalah 0,3 .

\section{Menentukan Peringkat Pada Akun TikTok}

Pada langkah terakhir yang dilakukan pada penelitian ini yaitu menentukan peringkat pada masing-masing rasio yang ada. Pada penentuan peringkat perlu melihat karakteristik dari rasio yang di teliti. Jika karakteristik rasio merupakan rendah, maka objek yang memiliki nilai terendah akan mendapatkan angka 5 dan objek yang memiliki nilai tertinggi akan mendapatkan angka 1. Namun jika rasio memiliki karakteritik tinggi maka objek yang mendapatkan nilai tinggi akan mendapatkan angka 5 dan objek yang mendapatkan nilai terendah akan mendapatkan angka 1. Setelah mendapatkan hasil kredibilitas ratio maka dapat disimpulkan objek yang mana mendapatkan peringkat 1 sampai dengan peringkat 5 . 


\section{HASIL DAN PEMBAHASAN}

Akun Youtube dari 5 Youtuber Terkaya Di Indonesia diantaranya:

\section{Deddy Corbuzier}

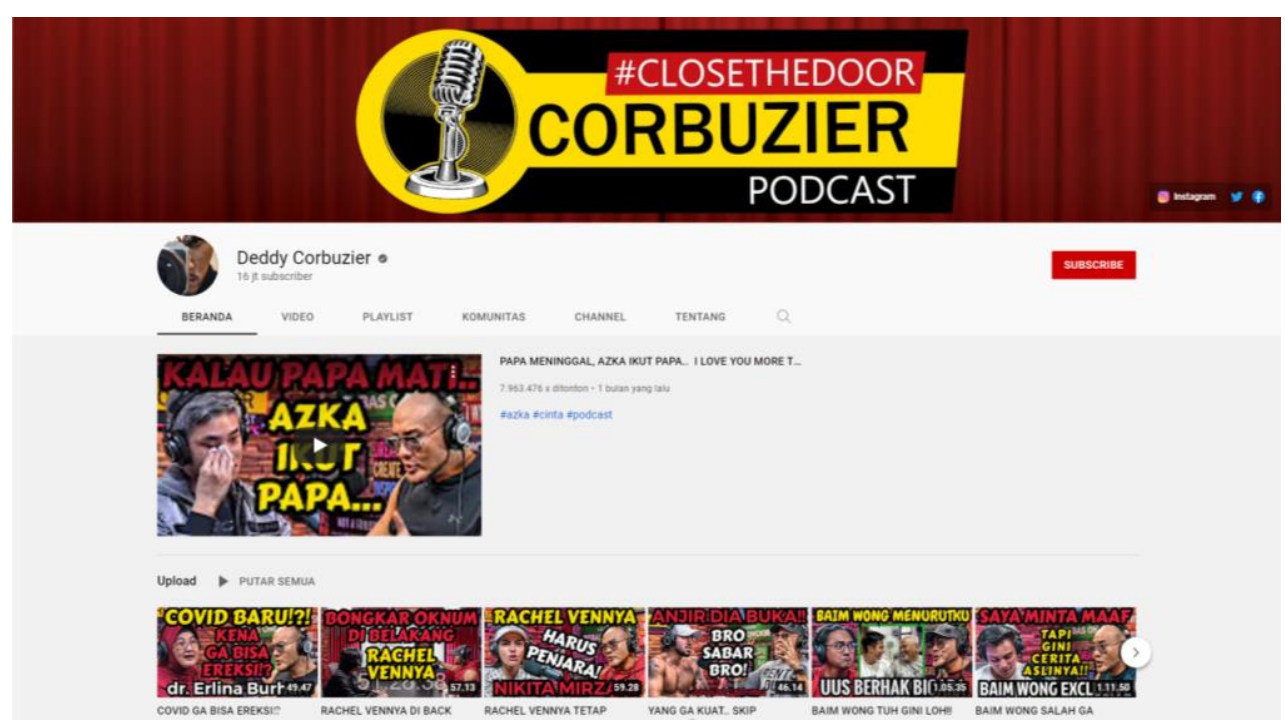

Gambar 1. Akun Youtube Deddy Corbuzier

Sumber : https://www.youtube.com/c/corbuzier (akses pada 22 Oktober 2021)

\section{Raffy Ahmad(Rans Entertaiment)}

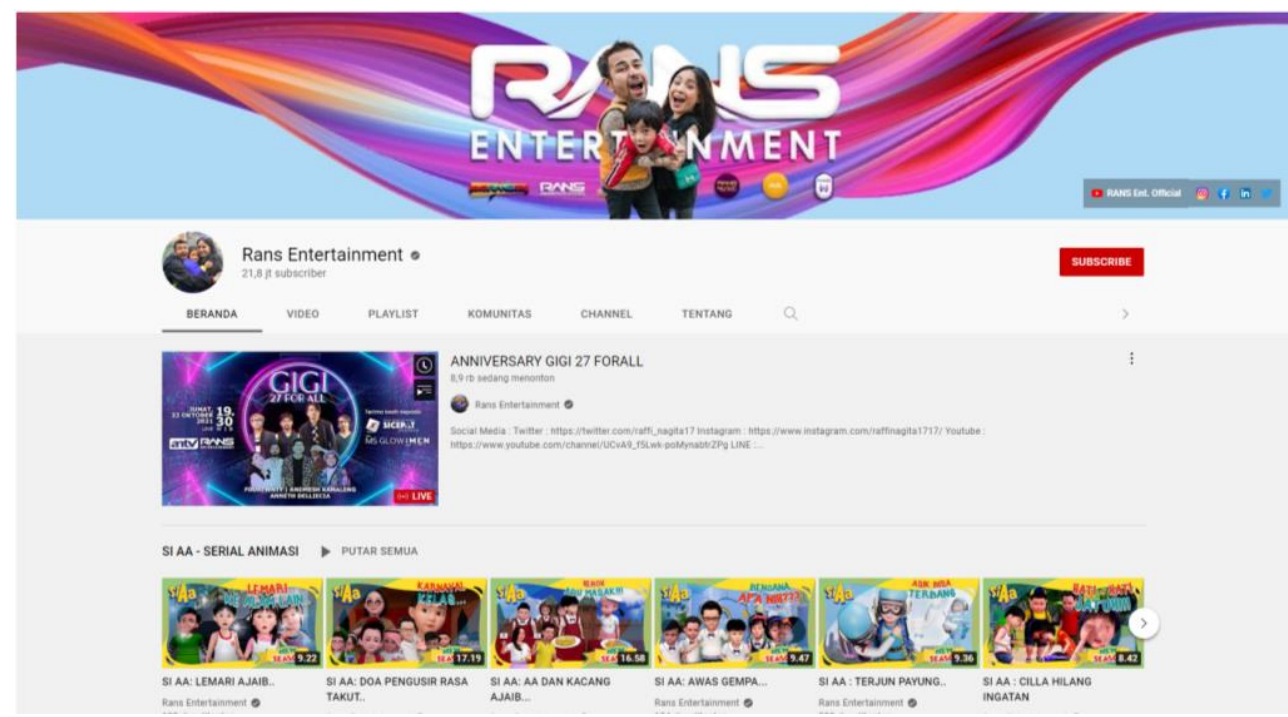

Gambar 2. Akun Youtube Raffy Ahmad

Sumber : https://www.youtube.com/c/RansEntertainment (akses pada 22 Oktober 2021) 


\section{Baim Paula}

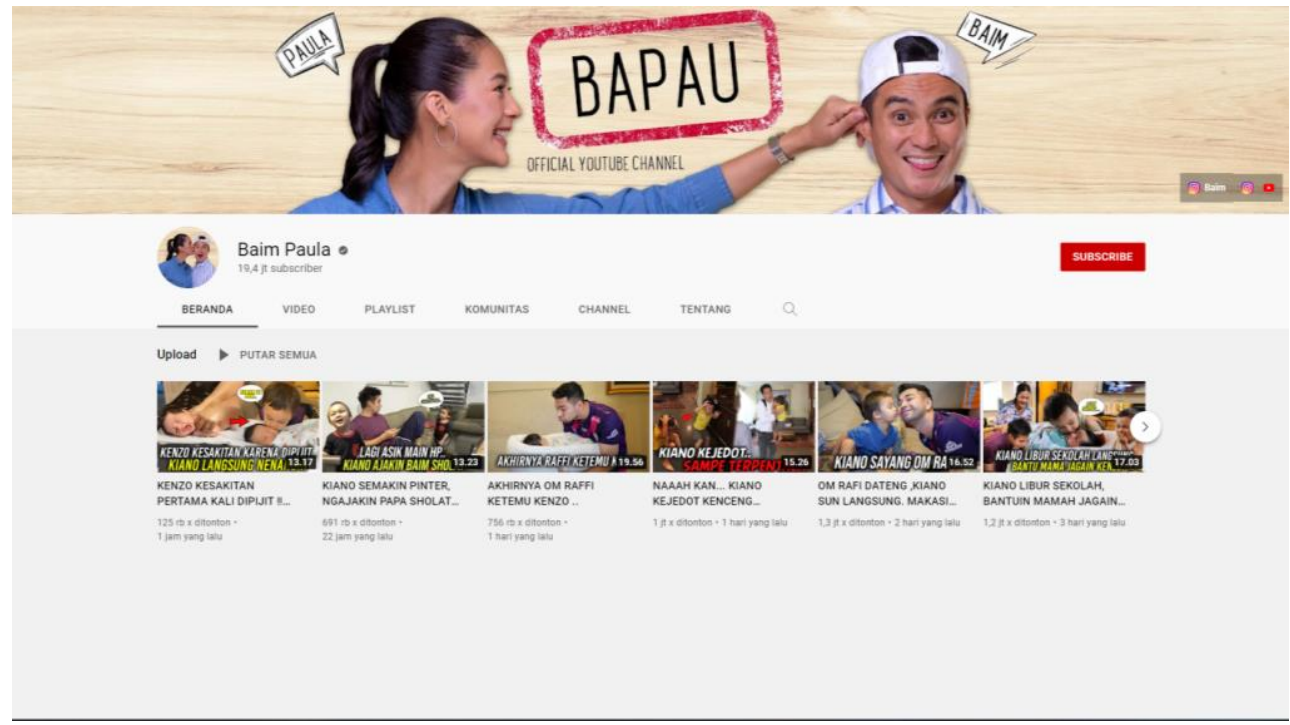

Gambar 3. Akun Youtube Baim Paula

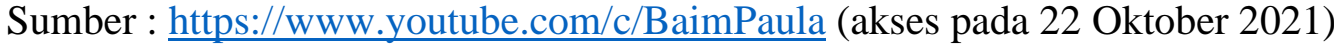

\section{Atta Halilintar}

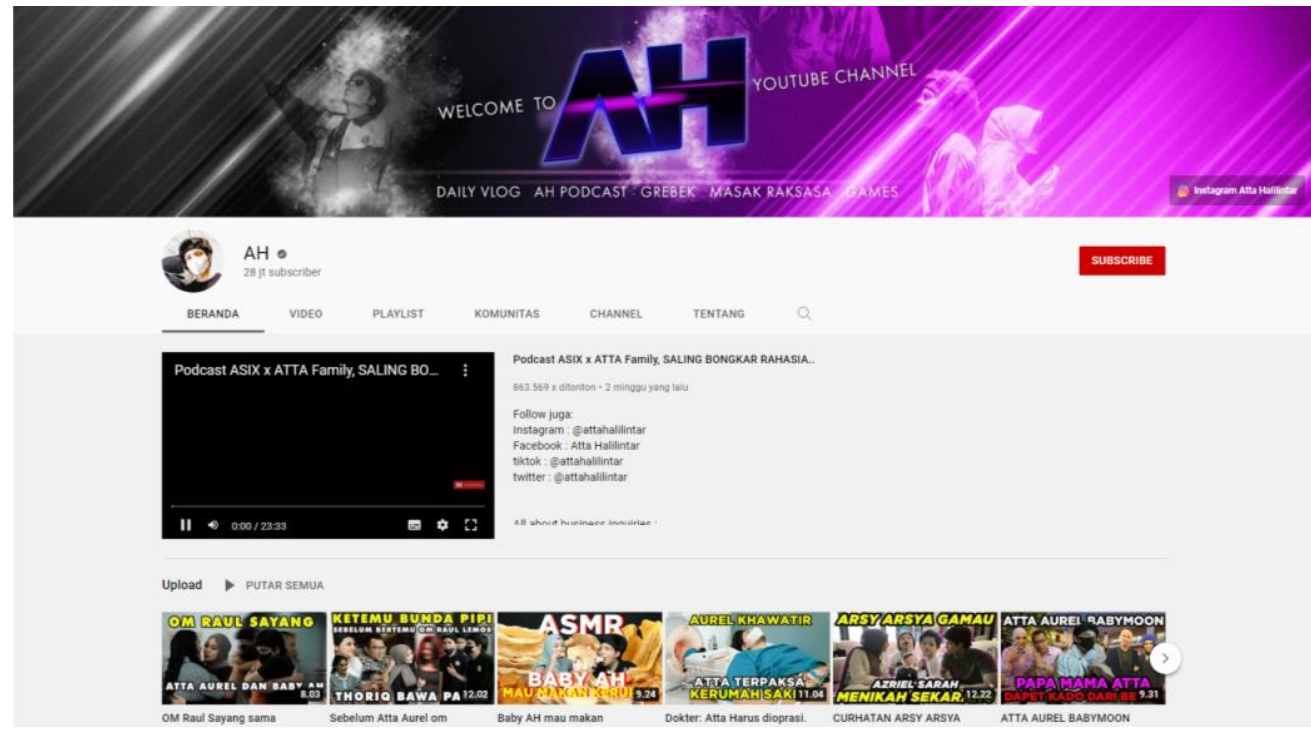

Gambar 4. Akun Youtube Atta Halilintar

Sumber : https://www.youtube.com/c/AttaHalilintar (akses pada 22 Oktober 2021) 


\section{Ria Ricis}

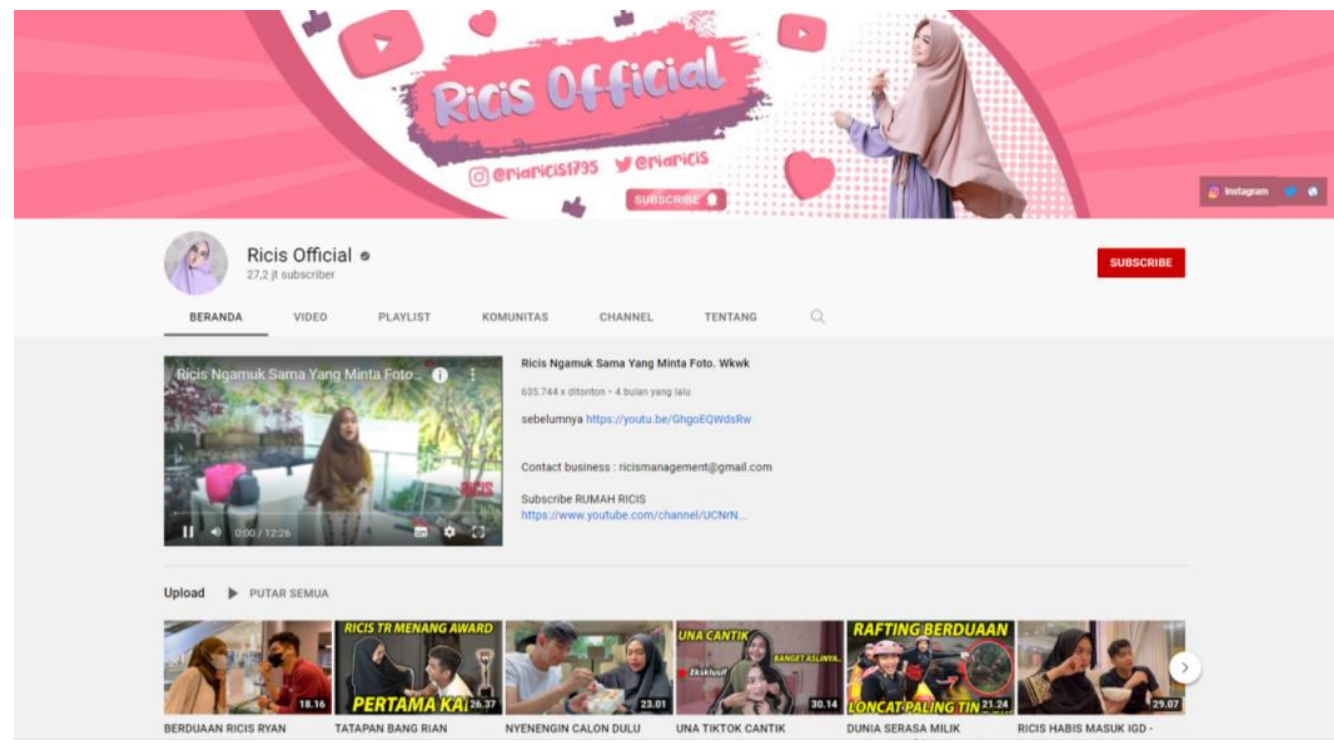

Gambar 5. Akun Youtube Ria Ricis

Sumber : https://www.youtube.com/c/Ricisofficial1795 (akses pada 22 Oktober 2021)

Dari Kelima akun Youtube dari 5 Youtuber Terkaya Di Indonesia, peneliti menemukan nilai dari masing-masing variabel yang ada untuk menghitung rasio Video Likes to Subscriber dari setiap akun. Pada akun Youtube terdapat 6 variabel, diantaranya yaitu :

1. Variabel Post

2. Variabel Subscriber

3. Variabel Likes

4. Variabel Dislikes

5. Variabel Viewers

6. Variabel Comments

Dari keenam variabel tersebut peneliti hanya fokus untuk menemukan hasil dari 2 variabel, yaitu :

1. Variabel Likes

2. Variabel Subscriber

Dari kedua variabel tersebut kemudian dianalisa sehingga menemukan nilai rata-rata dari variabel Likes dan variabel Subscriber. Untuk menghitung nilai rata-rata dari variabel Likes dan variabel Subscriber yaitu dengan cara mengambil minimal 10 postingan kemudian di 
hitung sehingga menemukan nilai rata-rata dari masing-masing variabel. Berikut merupakan tabel nilai rata-rata dari masing-masing Akun Youtuber Terkaya di Indonesia, yaitu :

Tabel 1. Analisa Nilai Rata-Rata Nilai Variabel Likes dan Subscriber Akun Youtube Deddy Corbuzier

\begin{tabular}{|c|c|c|}
\hline \multicolumn{3}{|c|}{ Deddy Corbuzier } \\
\hline NO & $\begin{array}{l}\text { VIDEO } \\
\text { LIKES }\end{array}$ & SUBSCRIBER \\
\hline 1 & 153.000 & \\
\hline 2 & 59.000 & \\
\hline 3 & 45.000 & \\
\hline 4 & 67.000 & \\
\hline 5 & 116.000 & 15.900 .000 \\
\hline 6 & 40.000 & \\
\hline 7 & 37.000 & \\
\hline 8 & 52.000 & \\
\hline 9 & 90.000 & \\
\hline 10 & 429.000 & \\
\hline TOTAL & 108.800 & 15.900 .000 \\
\hline
\end{tabular}

Sumber : Pengolahan Data Excel

Tabel 2. Analisa Nilai Rata-Rata Nilai Variabel Likes dan Subscriber Akun Youtube Raffy Ahmad

\begin{tabular}{|c|c|c|}
\hline \multicolumn{3}{|c|}{ Raffy Ahmad(Rans Entertaiment) } \\
\hline NO & $\begin{array}{l}\text { VIDEO } \\
\text { LIKES }\end{array}$ & SUBSCRIBER \\
\hline 1 & 19.000 & \\
\hline 2 & 31.000 & \\
\hline 3 & 75.000 & \\
\hline 4 & 14.000 & \\
\hline 5 & 114.000 & 21.800 .000 \\
\hline 6 & 1.600 & \\
\hline 7 & 1.300 & \\
\hline 8 & 2.200 & \\
\hline 9 & 1.600 & \\
\hline 10 & 4.200 & \\
\hline TOTAL & 26.390 & 21.800 .000 \\
\hline
\end{tabular}

Sumber : Pengolahan Data Excel 
Tabel 3. Analisa Nilai Rata-Rata Nilai Variabel Likes dan Subscriber Akun Youtube Baim Paula

Baim Paula

\begin{tabular}{|c|c|c|}
\hline NO & $\begin{array}{l}\text { VIDEO } \\
\text { LIKES }\end{array}$ & SUBSCRIBER \\
\hline 1 & 31.000 & \\
\hline 2 & 69.000 & \\
\hline 3 & 161.000 & \\
\hline 4 & 76.000 & \\
\hline 5 & 126.000 & 19.400 .000 \\
\hline 6 & 108.000 & \\
\hline 7 & 218.000 & \\
\hline 8 & 133.000 & \\
\hline 9 & 96.000 & \\
\hline 10 & 41.000 & \\
\hline TOTAL & 105.900 & 19.400 .000 \\
\hline
\end{tabular}

Sumber : Pengolahan Data Excel

Tabel 4. Analisa Nilai Rata-Rata Nilai Variabel Likes dan Subscriber Akun Atta Halilintar

\begin{tabular}{|c|c|c|}
\hline \multicolumn{3}{|c|}{ Atta Halilintar } \\
\hline NO & $\begin{array}{l}\text { VIDEO } \\
\text { LIKES }\end{array}$ & SUBSCRIBER \\
\hline 1 & 40.000 & \\
\hline 2 & 26.000 & \\
\hline 3 & 33.000 & \\
\hline 4 & 25.000 & \\
\hline 5 & 48.000 & 27.900 .000 \\
\hline 6 & 50.000 & \\
\hline 7 & 55.000 & \\
\hline 8 & 50.000 & \\
\hline 9 & 91.000 & \\
\hline 10 & 60.000 & \\
\hline TOTAL & 47.800 & 27.900 .000 \\
\hline
\end{tabular}

Sumber : Pengolahan Data Excel 
Tabel 5. Analisa Nilai Rata-Rata Nilai Variabel Likes dan Subscriber Akun Youtube Ria Ricis

\begin{tabular}{|c|c|c|}
\hline \multicolumn{3}{|c|}{ Ria Ricis } \\
\hline NO & $\begin{array}{l}\text { VIDEO } \\
\text { LIKES }\end{array}$ & SUBSCRIBER \\
\hline 1 & 81.000 & \\
\hline 2 & 79.000 & \\
\hline 3 & 95.000 & \\
\hline 4 & 89.000 & \\
\hline 5 & 118.000 & 27.100 .000 \\
\hline 6 & 107.000 & \\
\hline 7 & 107.000 & \\
\hline 8 & 110.000 & \\
\hline 9 & 87.000 & \\
\hline 10 & 90.000 & \\
\hline TOTAL & 96.300 & 27.100 .000 \\
\hline
\end{tabular}

Sumber : Pengolahan Data Excel

Setelah menghitung nilai rata-rata tersebut, maka akan menemukan hasil akhir nilai rata-rata dari variabel Likes dan Subscriber.

Tabel 6. Nilai Variabel Pada Akun Youtube 5 Youtuber Terkaya Di Indonesia Tabel Nilai Masing - Masing Variable

\begin{tabular}{|l|l|l|l|l|l|}
\hline Variable & Deddy Corbuzier & Raffy Ahmad & Baim Paula & Atta Halilintar & Ria Ricis \\
\hline Video Likes & 108.800 & 26.390 & 105.900 & 47.800 & 96.300 \\
\hline Subscriber & 15.900 .000 & 21.800 .000 & 19.400 .000 & 27.900 .000 & 27.100 .000 \\
\hline
\end{tabular}

Sumber : Pengolahan Data Excel

Pada Akun Youtube terdapat 10 ras rasio yang relevan digunakan untuk mengukur kredibilitas pada masing-masing akun. Namun pada penelitian kali ini hanya berfokus untuk menghitung Likes to Subscriber Ratio. Untuk menghitung kredibilitas dari masing-masing akun Youtube setiap Youtuber, peneliti menghitung dengan cara : variabel 1 akan dibagi dengan variabel 2, sehingga ditemukan hasil analisisa dari rasio tersebut. 
Tabel 7. Hasil Perhitungan Rasio Akun Youtube

\begin{tabular}{|l|ll|l|l|l|l|l|}
\hline \multicolumn{2}{|l|}{ Tabel Ratio } & & $\begin{array}{l}\text { Deddy } \\
\text { Corbuzier }\end{array}$ & $\begin{array}{l}\text { Raffy } \\
\text { Ahmad }\end{array}$ & $\begin{array}{l}\text { Baim } \\
\text { Paula }\end{array}$ & $\begin{array}{l}\text { Atta } \\
\text { Halilintar }\end{array}$ & Ria Ricis \\
\hline N & Ratio & TO & 0.0068427 & 0.0012105 & 0.0054587 & 0.0017132 & 0.0035535 \\
1 & LIKES & & 672955 & 504587 & 628865 & 616487 & 055350 \\
& SUBSCRIBER & & & & & \\
\hline
\end{tabular}

Sumber : Pengolahan Data Excel

Likes to Subscriber Ratio memiliki karakteristik yang tinggi, artinya semakin tinggi nilai yang dihasilkan maka semakin baik kredibilitas dari performa akun tersebut. Untuk memberikan peringkat pada masing-masing akun Youtuber, peneliti memberikan angka 5 kepada akun yang mendapatkan nilai tertinggi dan angka 1 untuk akun Youtube yang mendapatkan nilai terendah. Berikut merupakan tabel urutan nilai yang dihasilkan oleh masing-masing akun Youtuber.

Tabel 8. Nilai Rasio Akun Youtube dari 5 Youtuber Terkaya Di Indonesia

Tabel Peringkat
\begin{tabular}{|l|l|l|l|l|}
\hline Deddy Corbuzier & Raffy Ahmad & Baim Paula & Atta Halilintar & $\begin{array}{l}\text { Ria } \\
\text { Ricis }\end{array}$ \\
\hline 5 & 1 & 4 & 2 & 3 \\
\hline
\end{tabular}

Sumber : Pengolahan Data Excel

Dari Tabel Nilai Rasio Akun Youtube dari 5 Youtuber Terkaya Di Indonesia dapat disimpulkan bahwa Deddy Corbuzier mendapatkan nilai tertinggi untuk rasio Likes to Subscriber. Sedangkan Raffy Ahmad mendapatkan nilai terendah untuk rasio ini. Jadi, pada penelitian ini Deddy Corbuzier memiliki kredibilitas performa yang lebih baik dibandingkan dengan akun Youtuber lainnya. 


\section{KESIMPULAN}

Tujuan dari penelitian ini adalah mengetahui kredibilitas performa dari akun Youtube 5 Youtuber Terkaya Di Indonesia menggunakan Likes to Subscriber Ratio. 5 Youtuber Terkaya tersebut diantaranya : Deddy Corbuzier, Raffy Ahmad, Baim Paula, Atta Halilintar, dan Ria Ricis. Dari kelima akun Youtuber tersebut, dapat disimpulkan bahwa :

1. Peringkat pertama diraih oleh Youtuber Deddy Cirbuzier dengan nilai yaitu 0.0068427672955

2. Peringkat kedua diraih oleh Youtuber Baim Paula dengan nilai 0.0054587628865

3. Peringkat ketiga diraih oleh Yotuber Ria Ricis dengan nilai 0.0035535055350

4. Peringkat keempat diraih oleh Youtuber Atta Halilintar dengan nilai 0.0017132616487

5. Peringkat kelima diraih oleh Youtuber Raffy Ahmad dengan nilai 0.0012105504587

\section{DAFTAR PUSTAKA}

(Hendika Permana, 2021)Hendika Permana, I. P. (2021). Analisis Rasio Pada Akun Youtube Untuk Penelitian Kualitatif Menggunakan Metode Ekploratif. Jurnal Ilmiah Media Sisfo, 15(1), 40. https://doi.org/10.33998/mediasisfo.2021.15.1.970

(Rahmawan et al., 2018)Rahmawan, D., Mahameruaji, J. N., \& Janitra, P. A. (2018). Potensi Youtube Sebagai Media Edukasi Bagi Anak Muda. Edulib, 8(1), 81. https://doi.org/10.17509/edulib.v8i1.11267

Chandra, E. (2018). Youtube, Citra Media Informasi Interaktif Atau Media Penyampaian Aspirasi Pribadi. Jurnal Muara Ilmu Sosial, Humaniora, Dan Seni, 1(2), 406. https://doi.org/10.24912/jmishumsen.v1i2.1035

“5 YouTuber Terkaya di Indonesia Per Juli 2021, Siapa Nomor Satu?” Accessed October 22, 2021.https://www.pramborsfm.com/entertainment/5-youtuber-terkaya-di-indonesia-juli 2021 siapa-nomor-satu 